\title{
Sustained protection against distilled water provocation by a single dose of salmeterol in patients with asthma
}

\author{
G.P. Bootsma*, P.N.R. Dekhuijzen*, J. Festen*, J-W.J. Lammers**, P.G.H. Mulder+, \\ C.L.A. van Herwaarden*
}

Sustained protection against distilled water provocation by a single dose of salmeterol in patients with asthma. G.P. Bootsma, P.N.R. Dekhuijzen, J. Festen, J-W.J. Lammers, P.G.H. Mulder, C.L.A. van Herwaarden. OERS Journals Ltd 1997.

ABSTRACT: The long-acting $\beta_{2}$-agonist salmeterol inhibits in vitro the release of inflammatory mediators up to $20 \mathrm{~h}$. These mediators are involved in ultrasonically nebulized distilled water (UNDW)-induced bronchoconstriction. We investigated whether salmeterol provides prolonged protection against UNDW provocation and whether this effect was paralleled by its bronchodilator effects.

Nineteen asthmatic patients (mean forced expiratory volume in one second (FEV1) $\mathbf{8 4 . 8 \%}$ predicted, mean provocative concentration of histamine producing a $20 \%$ decrease in FEV1 $0.65 \mathrm{mg} \cdot \mathrm{mL}^{-1}$ ) participated in this randomized, double-blind, placebo-controlled crossover trial. After measuring baseline FEV1, patients inhaled $50 \mu \mathrm{g}$ salmeterol or placebo by metered-dose inhaler. FEV1 was measured after 20 and $40 \mathrm{~min}$, and UNDW provocations and FEV1 measurements were performed after 10, 20 and $34 \mathrm{~h}$.

Compared to placebo, salmeterol caused marked bronchodilatation from 20 min up to $20 \mathrm{~h}$ after inhalation. Salmeterol also provided more than $20 \mathrm{~h}$ of protection against UNDW provocation (still more than one doubling dose). Protection beyond the period of bronchodilatation did not occur. Eleven subjects had a significant reduction in provocative dose of UNDW causing a $20 \%$ fall in FEV1 (PD20,UNDW) values between 10 and $20 \mathrm{~h}$, at a time when there was still persistent bronchodilation. No correlation existed between changes in FEV1 and changes in PD20,UNDW. From the equations of regression lines between FEV1 and corresponding PD20,UNDW values, it was calculated that only $\sim 25 \%$ of the afforded protection was explained by bronchodilatation.

In conclusion, a single dose of salmeterol induces both bronchodilatation and protection independently of this bronchodilation against a physiological bronchoconstrictor stimulus for more than $20 \mathrm{~h}$.

Eur Respir J 1997; 10: 2230-2236.
*Dept of Pulmonary Diseases, University Hospital, Nijmegen. **Dept of Pulmonary Diseases, University Hospital, Utrecht. +Institute of Epidemiology and Biostatistics, Erasmus University, Rotterdam, The Netherlands.

Correspondence: G.P. Bootsma Dept of Pulmonary Diseases University Hospital Nijmegen P.O. Box 9101 6500 HB Nijmegen

The Netherlands

Keywords: Distilled water provocation protection

salmeterol

Received: December 281995

Accepted after revision July 71997

Supported by a grant from Glaxo B.V., The Netherlands

Medication supplied by Glaxo Research and Development, UK
The long-acting $\beta_{2}$-agonist salmeterol xinafoate has a higher potency and much longer duration of action than the short-acting $\beta_{2}$-agonists such as salbutamol [1]. Unlike the short-acting $\beta_{2}$-agonists, it has been suggested that salmeterol has some anti-inflammatory properties. In vitro data showed that salmeterol blocked mast cell mediator release 10-35 times more potently than salbutamol, with effects persisting for more than $20 \mathrm{~h}$ [2]. Salmeterol, but not salbutamol, also had inhibitory effects on other inflammatory cells such as eosinophils and alveolar macrophages [3], and afforded long-lasting inhibition of increases in vascular permeability [4]. Despite these cellular and vascular effects, evidence that they are of clinical relevance is still lacking. No change in bronchial hyperresponsiveness (BHR) was reported after 6 weeks of treatment with salmeterol [5] and analysis of bronchoalveolar lavage (BAL) cell profile has not shown convincing evidence of an anti-inflammatory effect [6].

On the other hand, TwENTYMAN et al. [7] suggested that salmeterol has some additional effects, i.e. preventing the increase in BHR after allergen provocation, beyond the time of bronchodilation. PEDERSEn et al. [8] also reported that salmeterol blocked the late asthmatic response and increase in BHR after allergen provocation.

In contrast to pharmacological stimuli such as histamine and methacholine, ultrasonically nebulized distilled water (UNDW) induces airway narrowing indirectly, by causing the release of endogenous mediators and possibly by initiating vagal reflex mechanisms $[9,10]$. Challenge with UNDW may increase BHR and induce a late asthmatic response, in the same manner as allergen exposure [10]. Thus, the mechanism by which UNDW provocation induces bronchoconstriction is likely to be similar to those involved in asthma provoked by naturally occurring stimuli [9]. If the above-mentioned long-lasting cell-stabilizing effect of salmeterol were present in vivo, this drug might be expected to afford prolonged protection against UNDW provocation.

The present study was, therefore, designed to assess whether a single dose of salmeterol provided long-lasting protection against UNDW provocation and whether or not this was caused by its bronchodilating properties. 


\section{Materials and methods}

\section{Study design}

This randomized, double-blind, placebo controlled, crossover trial consisted of two identical 3 day study periods, with a minimal interval of 1 week between the start of the two periods, in order to prevent any carryover effect. Subjects withheld rescue medication (salbutamol $100 \mu \mathrm{g}$ by metered dose inhaler (MDI)) at least $6 \mathrm{~h}$ before each visit and rested for at least $15 \mathrm{~min}$ before starting measurements.

On the first day, at $22.00 \mathrm{~h}$, baseline forced expiratory volume in one second (FEV1) was measured. Subsequently, study medication was administered, consisting of two inhalations of $25 \mu \mathrm{g}$ of salmeterol or placebo by MDI in random order. Flow-volume curves were recorded 20 and $40 \mathrm{~min}$ afterwards. On the second and third day, i.e. $10 \mathrm{~h}($ at $08.00 \mathrm{~h}), 20 \mathrm{~h}($ at $18.00 \mathrm{~h})$, and $34 \mathrm{~h}(08.00$ $\mathrm{h}$ the next day) after inhalation of the study medication, FEV1 measurements and a UNDW provocation were performed. Baseline FEV1 on the starting evening of both periods had to be within $10 \%$, otherwise the second period was postponed to a later day.

\section{Subjects}

Nineteen nonsmoking asthmatic patients ( 6 males, 13 females) according to the criteria of the American Thoracic Society [11], aged 16-54 (mean 28) yrs, entered the study. Sixteen persons were atopic, defined by an elevated specific immunoglobulin $\mathrm{E}$ or positive intracutaneous tests against house dust mite or two of seven other tested common aero-allergens [12]. At study entry, FEV1 had to be $\geq 50 \%$ predicted, and reversibility had to be $\geq 15 \%$ from prebronchodilator values in response to 200 $\mu \mathrm{g}$ salbutamol by MDI. The provocative concentration of histamine causing a $20 \%$ fall in FEV1 $\left(\mathrm{PC}_{20, \mathrm{H})}\right.$ [13] had to be below $4 \mathrm{mg} \cdot \mathrm{mL}^{-1}$ for all subjects. None had any significant medical condition or an upper or lower respiratory tract infection within 6 weeks before the study. Seasonally allergic persons were not measured during the time when exposure to such allergen was likely. During the study, the subjects used only salbutamol by MDI $(100 \mu \mathrm{g})$ as needed to control symptoms. Antiinflammatory treatment (inhaled corticosteroids, nedocromil sodium, and cromolyn sodium) were withheld for at least 6 weeks preceding the study and systemic steroids for at least 6 months. Methylxanthines were stopped at least $48 \mathrm{~h}$, anticholinergics and antihistamines at least $24 \mathrm{~h}$, before the start of the trial. The study was approved by the local hospital Ethics Committee; written informed consent was obtained from all participants.

\section{Methods}

The bronchodilator response and reactions to UNDW provocation were assessed by FEV1, obtained from flowvolume curves recorded on a heated pneumotachograph
(Spiro analyser ST 250®; Fukuda Sangyo Co., Tokyo). Baseline FEV1 was recorded from the best of three reproducible values (within 5\%).

The UNDW provocation test was performed according to the method described by GROOT et al. [14]. An ultrasonic nebulizer (Ultraneb 99, DeVilbiss, Somerset, PA, USA) was used at a fixed output of $2.00 \pm 0.05$ $\mathrm{mL} \cdot \mathrm{min}^{-1}$. The patient inhaled UNDW during tidal breathing through a mouthpiece with tightened lips and the nose clipped. A Wright respirometer (British Oxygen Co., London, UK) was connected to a two-way valve (Laerdal IV, Stavanger, Norway), placed in-between the aerosol hose and the mouthpiece, to measure the total volume of inhaled air. After inhalation of $20 \mathrm{~L}$ of ambient air through the system, doubling volumes of air with $\operatorname{UNDW}(3,5,10$, up to $160 \mathrm{~L})$ were successively inhaled at 5 min intervals. The response to inhaled UNDW was assessed by FEV1 after 90 and 180 s of each dose. The test was stopped if FEV1 dropped by at least $20 \%$ or if $160 \mathrm{~L}$ of air with UNDW was inhaled. Before and after each test, the nebulizer chamber and aerosol hose were weighted. The cumulative dose of inhaled distilled water in $\mathrm{mL} \mathrm{H}_{2} \mathrm{O}$ causing a $20 \%$ fall in FEV 1 from post-air values (PD20,UNDW), was calculated by linear interpolation on a semilogarithmic curve.

Pretrial PC20,H was measured according to the method of Cockroft et al. [13]. In short, the patient inhaled doubling doses of histamine phosphate from 0.03 to 16 $\mathrm{mg} \cdot \mathrm{mL}^{-1}$. The test was stopped if FEV1 fell $20 \%$ from baseline, and a log dose-response curve was constructed. The $\mathrm{PC}_{20, \mathrm{H}}$ was calculated in $\mathrm{mg} \cdot \mathrm{mL}^{-1}$ by linear interpolation.

\section{Statistical analysis}

All PD20,UNDW data were $\log 10$ transformed before analysis. FEV1 data were expressed as \% pred [15]. To calculate the treatment effect of salmeterol, differences between values (FEV1 and PD20,UNDW) on salmeterol and on placebo were calculated and tested at each timepoint with the Wilcoxon signed rank test. The change in UNDW responsiveness ( $\triangle$ PD20,UNDW) was expressed in doubling doses (DD), calculated as:

\section{((logPD20,UNDW-salmeterol)-} $(\log P$ D20,UNDW-placebo) $) / \log 2$

Period and carry-over effects were analysed according to $\mathrm{Koch}$ [16]. The coefficient of repeatability for PD20,UNDW was calculated for each subject using the two UNDW provocations in the placebo period (baseline), at the same time of the day (08:00 h) according to the method of Bland and Altman [17]. Correlations between variables were performed with the Spearman correlation test. Regression lines were compared with analysis of variance (ANOVA) of repeated measurements. For multiple comparisons, a Bonferroni correction was used. A p-value of 0.05 or less was considered significant for one test. For multiple comparisons, this boundary was set at 0.01 . Data are reported as mean values (SEM). 


\section{Results}

Patient characteristics are listed in table 1. Seventeen patients completed the study. Two persons (subjects No. 2 and 8 ) failed to return to the laboratory for lung function and provocation tests for the second treatment period (both after placebo in period one) and were withdrawn from the study. There were no period or carry-over effects between the two study periods at any time-point with regard to FEV1 and PD20,UNDW data.
Baseline FEV1 and changes during study medication

Baseline FEV1 at $22.00 \mathrm{~h}$ on the starting day of both periods was similar with a variation of $1.8 \%$ (range $0.3-9.7 \%$ pred).

Salmeterol caused a significant and substantial degree of bronchodilatation versus placebo from $20 \mathrm{~min}$ up to $20 \mathrm{~h}$ after inhalation (per cent increase from baseline after salmeterol 14.8 (2.1), 17.7 (2.3), 13.9 (3.2) and 12.7 (1.7) $1 \%$ after 20 and $40 \mathrm{~min}$ and 10 and $20 \mathrm{~h}$, respectively; all time-points significantly different from placebo $(\mathrm{p}<0.001)$, except for $34 \mathrm{~h}(\mathrm{p}=0.55))($ table 2$)$.

Table 1. - Characteristics of the study subjects

\begin{tabular}{|c|c|c|c|c|c|c|c|}
\hline $\begin{array}{c}\text { Subject } \\
\text { No. }\end{array}$ & Sex & $\begin{array}{l}\text { Age } \\
\text { yrs }\end{array}$ & Atopic & $\begin{array}{l}\text { FEV1 } \\
\% \text { pred }\end{array}$ & $\begin{array}{c}\text { Reversibility } * \\
\%\end{array}$ & $\begin{array}{l}\mathrm{PC}_{20, \mathrm{H}} \\
\mathrm{mg} \cdot \mathrm{mL}^{-1}\end{array}$ & Medication $^{+}$ \\
\hline 1 & M & 33 & Yes & 85.2 & 15.1 & 0.33 & B \\
\hline 2 & $\mathrm{~F}$ & 23 & Yes & 95.0 & 15.6 & 0.09 & B \\
\hline 3 & M & 26 & Yes & 99.6 & 17.4 & 0.36 & B \\
\hline 4 & M & 25 & Yes & 64.0 & 24.5 & 1.09 & B \\
\hline 5 & $\mathrm{~F}$ & 18 & Yes & 56.2 & 31.7 & 0.08 & $\mathrm{~B}, \mathrm{~T}$ \\
\hline 6 & M & 39 & Yes & 85.6 & 18.5 & 0.71 & $\mathrm{~B}, \mathrm{C}$ \\
\hline 7 & $\mathrm{~F}$ & 42 & No & 59.0 & 26.9 & 0.07 & B \\
\hline 8 & $\mathrm{~F}$ & 26 & Yes & 99.7 & 15.6 & 0.15 & B \\
\hline 9 & F & 16 & Yes & 106.3 & 15.6 & 0.10 & B \\
\hline 10 & M & 22 & Yes & 77.6 & 26.1 & 0.62 & B \\
\hline 11 & $\mathrm{~F}$ & 27 & Yes & 96.3 & 19.2 & 0.15 & B \\
\hline 12 & $\mathrm{~F}$ & 22 & No & 99.7 & 15.1 & 1.05 & B \\
\hline 13 & $\mathrm{~F}$ & 26 & Yes & 100.3 & 27.9 & 0.25 & B \\
\hline 14 & $\mathrm{~F}$ & 23 & Yes & 90.3 & 19.7 & 0.90 & B \\
\hline 15 & M & 18 & Yes & 60.2 & 46.4 & 0.07 & A,B \\
\hline 16 & $\mathrm{~F}$ & 54 & No & 103.3 & 30.9 & 1.98 & B \\
\hline 17 & $\mathrm{~F}$ & 31 & Yes & 76.4 & 16.7 & 3.62 & B \\
\hline 18 & $\mathrm{~F}$ & 27 & Yes & 84.9 & 18.7 & 0.25 & $\mathrm{~B}, \mathrm{IC}$ \\
\hline 19 & $\mathrm{~F}$ & 26 & Yes & 77.3 & 22.5 & 0.54 & $\mathrm{~B}, \mathrm{C}$ \\
\hline Mean & & 27.6 & & 85.1 & 22.3 & 0.65 & \\
\hline SEM & & 2.1 & & 3.7 & 1.8 & 0.20 & \\
\hline
\end{tabular}

*: reversibility to salbutamol $200 \mu \mathrm{g}$ by metered-dose inhaler (\% change from prebronchodilator value). ${ }^{+}$: therapy until 6 weeks before participation in the study. PC20,H: provocative concentration of histamine causing a $20 \%$ fall in forced expiratory volume in one second; A: anticholinergic; B: $\beta_{2}$-agonist; $\mathrm{C}$ : cromolyn sodium; IC: inhaled corticosteroids; T: oral theophylline; M: male; F: female.

Table 2. - Individual data of forced expiratory volume in one second (percentage of predicted value)

\begin{tabular}{|c|c|c|c|c|c|c|c|c|c|c|c|}
\hline \multirow{3}{*}{$\begin{array}{c}\text { Patient } \\
\text { No. }\end{array}$} & \multirow[b]{3}{*}{ Baseline } & \multicolumn{10}{|c|}{ Time after inhalation } \\
\hline & & \multicolumn{2}{|c|}{$20 \mathrm{~min}$} & \multicolumn{2}{|c|}{$40 \mathrm{~min}$} & \multicolumn{2}{|c|}{$10 \mathrm{~h}$} & \multicolumn{2}{|c|}{$20 \mathrm{~h}$} & \multicolumn{2}{|c|}{$34 \mathrm{~h}$} \\
\hline & & SLM & Placebo & SLM & Placebo & SLM & Placebo & SLM & Placebo & SLM & Placebo \\
\hline 1 & 84.5 & 103.1 & 84.3 & 105.6 & 87.2 & 93.1 & 81.1 & 92.8 & 82.8 & 82.8 & 80.6 \\
\hline 3 & 106.0 & 115.8 & 104.9 & 119.0 & 108.0 & 113.6 & 106.0 & 113.4 & 116.0 & 98.4 & 103.0 \\
\hline 4 & 55.1 & 63.2 & 56.6 & 67.3 & 60.9 & 63.8 & 44.1 & 60.7 & 56.4 & 54.3 & 44.6 \\
\hline 5 & 54.2 & 64.3 & 56.4 & 67.9 & 53.4 & 46.0 & 38.9 & 64.6 & 55.3 & 57.8 & 60.5 \\
\hline 6 & 85.0 & 91.0 & 86.4 & 96.2 & 85.8 & 95.1 & 73.1 & 88.4 & 89.9 & 75.2 & 81.2 \\
\hline 7 & 49.0 & 53.5 & 50.9 & 53.5 & 51.2 & 59.7 & 50.9 & 66.4 & 50.9 & 52.7 & 50.5 \\
\hline 9 & 109.4 & 119.4 & 108.0 & 120.2 & 109.1 & 121.7 & 112.8 & 117.1 & 115.7 & 117.1 & 113.4 \\
\hline 10 & 76.7 & 95.0 & 73.8 & 98.6 & 77.3 & 95.8 & 71.2 & 99.0 & 80.9 & 88.8 & 66.6 \\
\hline 11 & 95.6 & 114.5 & 99.6 & 112.3 & 101.8 & 124.3 & 100.9 & 108.0 & 100.6 & 99.0 & 100.3 \\
\hline 12 & 94.6 & 100.5 & 94.0 & 107.0 & 82.1 & 98.3 & 70.8 & 108.2 & 79.8 & 63.4 & 73.6 \\
\hline 13 & 68.8 & 105.5 & 60.0 & 104.3 & 58.3 & 106.1 & 62.9 & 90.9 & 72.3 & 68.8 & 83.0 \\
\hline 14 & 94.9 & 111.1 & 94.4 & 111.7 & 100.0 & 111.1 & 90.3 & 111.9 & 102.5 & 100.2 & 92.8 \\
\hline 15 & 61.2 & 75.4 & 65.1 & 82.5 & 60.6 & 86.0 & 56.5 & 75.2 & 49.8 & 46.2 & 46.4 \\
\hline 16 & 87.7 & 118.7 & 80.2 & 123.9 & 81.6 & 102.3 & 89.6 & 104.2 & 89.6 & 84.0 & 86.3 \\
\hline 17 & 81.2 & 92.6 & 81.8 & 94.2 & 83.4 & 92.9 & 80.8 & 92.3 & 85.0 & 81.5 & 78.2 \\
\hline 18 & 90.6 & 98.1 & 83.7 & 97.2 & 86.1 & 100.6 & 78.6 & 94.8 & 83.1 & 82.5 & 54.2 \\
\hline 19 & 93.8 & 97.3 & 90.2 & 95.8 & 91.4 & 97.0 & 90.2 & 92.9 & 93.5 & 86.1 & 81.4 \\
\hline Mean & 81.7 & 95.2 & 80.6 & 97.5 & 81.1 & 94.5 & 76.4 & 93.0 & 82.6 & 78.7 & 76.3 \\
\hline SEM & 4.4 & 4.9 & 4.3 & 4.8 & 4.5 & 5.1 & 5.1 & 4.2 & 5.0 & 4.7 & 4.9 \\
\hline
\end{tabular}

SLM: salmeterol. 
The early morning dip seen after treatment with placebo (at $08.00 \mathrm{~h}$ ) (mean change in $\mathrm{FEV}_{1}-7.2 \%$, range -28 to +5 , compared to $22.00 \mathrm{~h}$ ) was completely abolished in all but one patient $(\mathrm{p}<0.001)$. The next morning (34 $\mathrm{h}$ after inhalation), salmeterol no longer provided protection against a morning dip.

\section{UNDW provocation tests}

Two of the 17 persons differed in their response to UNDW provocation from the others. Subject No. 1 appeared to be unresponsive to UNDW provocation. He recovered very fast from the constrictor effects of UNDW and showed a plateau in reaction of FEV1 at $80 \%$ of the post-air values. Subject No. 10 turned out to be refractory to subsequent UNDW provocation tests. PD20,UNDW increased at subsequent tests, and he ended totally unresponsive at the third test (table 3). For these two patients, no real treatment effect of salmeterol could be calculated, but exclusion of their data did not alter the levels of significance for the major outcome variables. The other 15 subjects demonstrated a good short-term reproducibility of PD20,UNDW. The standard deviation of the differences for baseline UNDW provocations was 0.67 DD.

In the whole group $(n=17)$, treatment with salmeterol resulted in protection against UNDW-induced bronchoconstriction for at least $20 \mathrm{~h}$ (table 3 ). Ten hours after the inhalation of salmeterol, a significant increase was observed in the PD20,UNDW of 16.7 (2.3) $\mathrm{mL} \mathrm{H}_{2} \mathrm{O}$ as compared with $3.3(1.4) \mathrm{mL} \mathrm{H}_{2} \mathrm{O}$ after placebo (treatment effect of $2.82(0.35) \mathrm{DD}, \mathrm{p}<0.0001)$. In nine of the 17 subjects, the maximum dose of UNDW was reached. In these patients, the total amount of $\mathrm{mL} \mathrm{H}_{2} \mathrm{O}$ inhaled

Table 3. - Individual data of PD20

\begin{tabular}{|c|c|c|c|c|c|c|}
\hline \multirow{3}{*}{$\begin{array}{c}\text { Patient } \\
\text { No. }\end{array}$} & \multicolumn{6}{|c|}{ Time after inhalation } \\
\hline & \multicolumn{2}{|c|}{$10 \mathrm{~h}$} & \multicolumn{2}{|c|}{$20 \mathrm{~h}$} & \multicolumn{2}{|c|}{$34 \mathrm{~h}$} \\
\hline & SLM & Placebo $^{\#}$ & SLM & Placebo & SLM & Placebo\# \\
\hline 1 & 19.3 & 25.0 & 6.1 & 10.9 & 11.2 & 21.2 \\
\hline 3 & 15.4 & 2.6 & 2.7 & 4.8 & 1.3 & 1.9 \\
\hline 4 & 1.7 & 0.9 & 1.3 & 1.2 & 1.7 & 1.3 \\
\hline 5 & 1.0 & 0.3 & 1.9 & 0.4 & 0.2 & 0.5 \\
\hline 6 & 18.5 & 6.3 & 10.6 & 7.6 & 10.0 & 6.5 \\
\hline 7 & 21.7 & 0.7 & 6.7 & 1.8 & 2.2 & 2.8 \\
\hline 9 & 19.9 & 0.9 & 4.7 & 1.0 & 2.7 & 1.3 \\
\hline 10 & 30.1 & 1.7 & 25.6 & 6.1 & 27.3 & 31.2 \\
\hline 11 & 12.2 & 3.4 & 7.7 & 3.0 & 2.1 & 3.8 \\
\hline 12 & 23.1 & 1.9 & 3.2 & 2.2 & 2.7 & 1.9 \\
\hline 13 & 12.9 & 0.9 & 1.9 & 0.9 & 0.8 & 1.3 \\
\hline 14 & 17.5 & 1.7 & 17.3 & 5.7 & 5.3 & 2.1 \\
\hline 15 & 8.9 & 1.0 & 1.7 & 1.0 & 2.0 & 1.0 \\
\hline 16 & 11.9 & 2.4 & 4.0 & 1.5 & 3.74 & 2.9 \\
\hline 17 & 8.3 & 1.8 & 10.7 & 3.2 & 1.2 & 2.0 \\
\hline 18 & 37.2 & 1.6 & 6.8 & 1.4 & 1.9 & 0.8 \\
\hline 19 & 23.2 & 1.6 & 5.6 & 2.8 & 5.4 & 2.7 \\
\hline Mean & 16.7 & 3.3 & 7.0 & 3.3 & 4.8 & 5.0 \\
\hline SEM & 2.3 & 1.4 & 1.5 & 0.7 & 1.6 & 2.0 \\
\hline
\end{tabular}

SLM: salmeterol; PD20: provocative dose causing a $20 \%$ fall in forced expiratory volume in one second; \#: data used for the coefficient of repeatability (excluded patients Nos. 1 and 10 ; see text). at that time was taken for analysis, since no PD20,UNDW could be reached after salmeterol. Twenty hours after inhalation (at $18.00 \mathrm{~h}$ ) there was still a significant protection for UNDW, with a PD20,UNDW of 7.0 (1.5) $\mathrm{mL}$ $\mathrm{H}_{2} \mathrm{O}$ after salmeterol as compared with $3.3(0.7) \mathrm{mL}$ $\mathrm{H}_{2} \mathrm{O}$ after placebo (treatment effect of 1.09 (0.23) DD, $\mathrm{p}=0.0008$ ). After $34 \mathrm{~h}$ (at $08.00 \mathrm{~h}) \mathrm{PD} 20$, UNDW values returned to placebo level $\left(4.8(1.6) \mathrm{mLH}_{2} \mathrm{O}\right.$ after salmeterol as compared with $5.0(2.0) \mathrm{mL} \mathrm{H}_{2} \mathrm{O}$ after placebo (treatment effect of $0.1(0.2) \mathrm{DD}, \mathrm{p}=0.55)$ ).

\section{Relationship between UNDW provocation and airway calibre}

For each time-point, $\triangle \mathrm{PD} 20, \mathrm{UNDW}$ was not correlated with the corresponding change in FEV1 $(\Delta \mathrm{FEV} 1)$ from placebo to salmeterol (all $\mathrm{r}<0.11, \mathrm{p}>0.65$ ).

Figure 1 shows the FEV1 and corresponding PD20,UNDW values of the individual patients 10 and $20 \mathrm{~h}$ (fig. 1a), and 20 and $34 \mathrm{~h}$ (fig. 1b) after inhalation of salmeterol. From 10 to $20 \mathrm{~h}$, in most individual patients and as a group, FEV1 did not change $(p=0.38)$, while PD20,UNDW dropped significantly ( $\mathrm{p}=0.002$, fig. $1 \mathrm{~b})$. From 20 to $34 \mathrm{~h}$, both mean FEV1 and mean PD20,UNDW decreased significantly ( $\mathrm{p}<0.001$ and $\mathrm{p}=0.02$, respectively), but again some individual patients showed (almost) no decrease in FEV1, while PD20,UNDW dropped (lines appear roughly vertical), while other patients exhibited a decrease in FEV1 with no change in PD20, (lines are more or less horizontal). Both time courses indicate that the protection afforded by salmeterol was independent from bronchodilation.

The slopes of the regression lines through these points after 10 and 20, but not after $34 \mathrm{~h}$ on salmeterol and placebo differed significantly from zero $(\mathrm{p}=0.001$ and $\mathrm{p}=0.03$, respectively), indicating a (linear) relationship between starting airway calibre and BHR. The slopes between the regression lines of salmeterol in comparison with placebo were not different at any time-point (all p>0.49), but again, both after 10 and $20 \mathrm{~h}$, the treatment effect of salmeterol was highly significant, placing the lines after salmeterol parallel at a higher level compared to placebo $(\mathrm{p}=0.000$ and $\mathrm{p}=0.002$, respectively). Previously, it has been shown that there is a linear relationship between FEV1 and the provocative concentration of methacholine causing a $20 \%$ fall in FEV1 (PC20,M) [18]. Under the assumption of a similar relationship between FEV1 and PD20,UNDW and because the measurements on salmeterol and on placebo are paired, the relationship between PD20,UNDW, and FEV1 can be describe statistically with one equation for the regression lines at each time-point:

$$
\begin{gathered}
\text { after } 10 \mathrm{~h} \text { : PD20,UNDW }=-0.747+1.075 \text { treatment }+ \\
0.035 \times \mathrm{FEV} 1 \\
\text { after } 20 \mathrm{~h}: \text { PD20,UNDW }=-0.636+0.408 \text { treatment }+ \\
0.028 \times \mathrm{FEV} 1
\end{gathered}
$$

where treatment is assigned a value of +1 for salmeterol and -1 for placebo.

$\triangle \mathrm{PD} 20, \mathrm{UNDW}$ is 2.8 and $1.1 \mathrm{DD}$, and $\triangle \mathrm{FEV} 1$ is $18.4 \%$ and $10.4 \%$, after 10 and $20 \mathrm{~h}$, respectively. It follows from the equation that $10 \mathrm{~h}$ after inhaling salmeterol, 

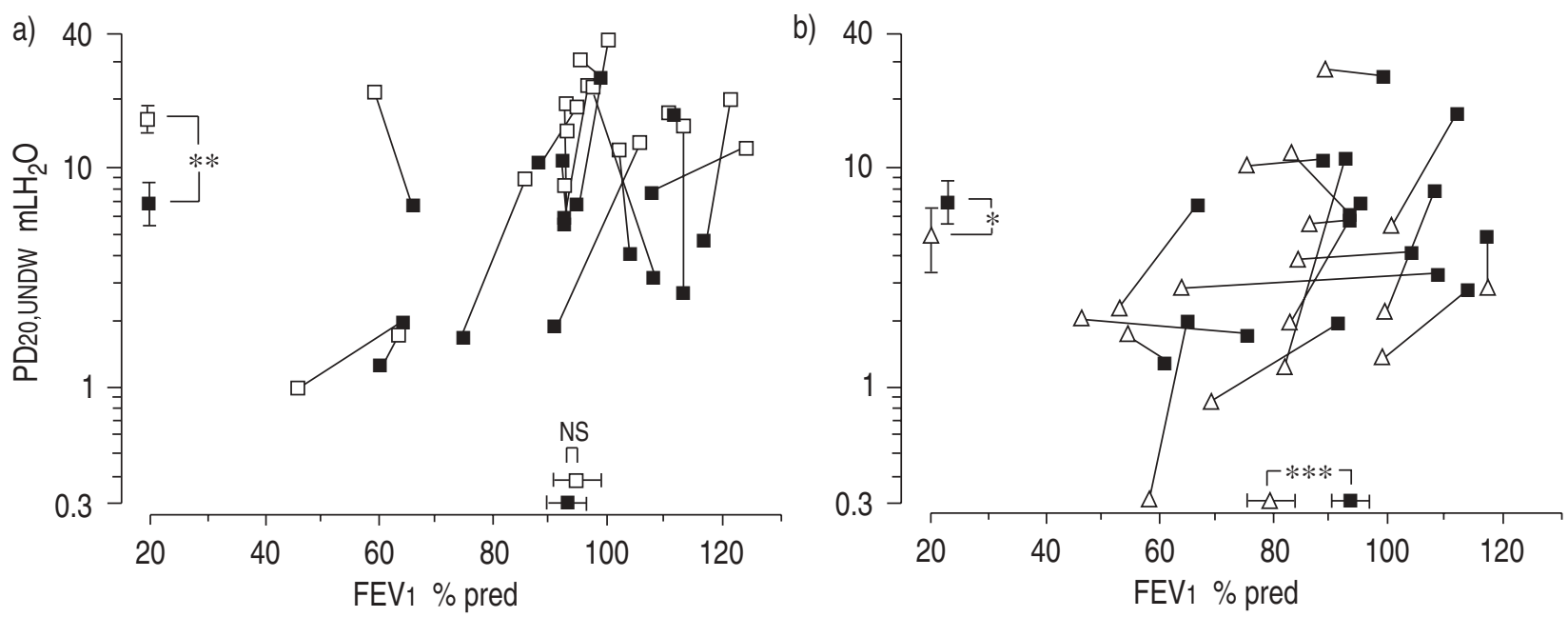

Fig. 1. - The change in FEV1 and corresponding PD20,UNDw points in each patient, from: a) 10-20 h; and b) 20-34 h after inhalation of salmeterol. $\square: 10 \mathrm{~h} ; \boldsymbol{\square}: 20 \mathrm{~h} ; \Delta: 34 \mathrm{~h}$ after inhalation of salmeterol. Mean (SEM) values of FEV 1 and PD20,UNDW are shown at the corresponding axes: *: p<0.05; **: p<0.01; ***: p<0.001; Ns: nonsignificant. FEV1: forced expiratory volume in one second; PD20,UNDW: provocative dose of ultrasonically nebulized distilled water causing a $20 \%$ fall of FEV1; $\%$ pred: percentage of predicted value.

the treatment effect is $+2.15 \mathrm{DD}$ and the effect through FEV 1 is $0.035 \times 18.4=0.65$, hence $2.8 \mathrm{DD}$ as found in the study. After $20 \mathrm{~h}$, the treatment effect is +0.82 and the effect through FEV 1 is $0.028 \times 10.4=0.29$ (hence the real found protection of $1.1 \mathrm{DD})$. This means that only $23 \%(0.65 / 2.80 \times 100 \%)$ of the afforded protection can be explained by bronchodilation, and $77 \%$ by a direct effect of salmeterol. After $20 \mathrm{~h}$ these values are 26 and $74 \%$, respectively.

\section{Discussion}

This study shows that a single dose of salmeterol affords both bronchodilation and protection against UNDW provocation up to $20 \mathrm{~h}$ in asthmatic patients who did not use anti-inflammatory medication. Protection against UNDW provocation beyond the period of bronchodilation did not occur. In 11 of 17 patients, the inhibition of bronchoconstriction to UNDW decreased significantly between 10 and $20 \mathrm{~h}$, at which time bronchodilation persisted. However, protection was still more than 1 DD after $20 \mathrm{~h}$, and up to this time, only a maximum of $26 \%$ of the protection could be explained by the bronchodilating effect of salmeterol.

The duration of protection against UNDW challenge was in line with the in vitro activity of salmeterol. UNDW provocation is thought to be mediated by the release of mast cell mediators $[9,10]$. Salmeterol inhibits the release of these mediators from sensitized human lung fragments for more than $20 \mathrm{~h}$ [2]. In the present study, a single dose of salmeterol afforded protection at $10 \mathrm{~h}$ of almost $3 \mathrm{DD}$, and, although the magnitude of the protection weaned, protection was still more than 1 DD after $20 \mathrm{~h}$. In this way, salmeterol showed, in vivo, a relevant protection during the period of blocking mediators in vitro [2].

In accordance with Воотн et al. [19], no increase in BHR after withdrawal of salmeterol was found in our study. Thirty four hours after inhalation of salmeterol (more than three times the half-life), no rebound BHR to UNDW occurred, the PD20,UNDW being $0.12 \mathrm{DD}$ above placebo.
Salmeterol also induced bronchodilation for more than $20 \mathrm{~h}$, and protected against the early morning dip $10 \mathrm{~h}$ after inhalation. TWENTYMAN et al. [7] tested bronchodilation of a single dose of salmeterol up to $34 \mathrm{~h}$, but regular measurements were discontinued after 9.5 $\mathrm{h}$. When starting measurements again after $32 \mathrm{~h}$, salmeterol no longer afforded bronchodilation. In a group of asthmatic patients with similar characteristics as in the present study, RABE et al. [20] showed that salmeterol decreased airway tone significantly over a whole $24 \mathrm{~h}$ period, compared with placebo. Because of multiple comparisons, however, the bronchodilating effect was not significant beyond $12 \mathrm{~h}$ at the individual timepoints. Our study clearly shows a bronchodilation up to $20 \mathrm{~h}$, which disappeared after $34 \mathrm{~h}$.

Besides bronchodilation, an important property of salmeterol could be the ability to afford protection of airways smooth muscle against bronchoconstrictor mediators with time-course characteristics different from those observed for bronchodilation [7]. Since baseline airway function correlates somewhat with airway reactivity [18], the inhibitory effect of a bronchodilator could be due to a change in airway calibre. In this study, both bronchodilation and protection lasted more than $20 \mathrm{~h}$ but less than $34 \mathrm{~h}$. More measurements of UNDW provocation during this period would be needed to determine exactly the duration of action and to distinguish between protection and bronchodilation. However, we made measurements at $10 \mathrm{~h}$ intervals to avoid confounding problems such as a temporary (small) increase in BHR after UNDW provocation $[10,21]$, and to avoid refractoriness after repeated UNDW measurements [14, 21], which may persist up to $4 \mathrm{~h}$ after the last challenge [22, 23]. Despite this, two patients (subjects No. 2 (dropped out) and 10) became refractory to successive UNDW provocations.

No correlation was found between bronchodilation $(\triangle \mathrm{FEV} 1)$ and protection $(\triangle \mathrm{PD} 20, \mathrm{UNDW})$ provided by salmeterol at any time-point, indicating that protection was not caused by bronchodilation. However, the number of patients in our study is probably too small to state that there might not be a correlation with a much larger 
population. On the other hand, figure 1 shows that in individual patients the protection afforded by salmeterol is independent of airway calibre, and there were moderate-to-severe responses to inhalation to water at a time when airway calibre was optimal. The regression lines through these points again show a highly significant treatment effect of salmeterol, by shifting the lines at 10 and $20 \mathrm{~h}$ parallel to higher levels than after placebo. From the equations of the regression lines on salmeterol and on placebo at the various time-points, it can be calculated that up to $20 \mathrm{~h}$, only a maximum of $26 \%$ of the protection can be explained by the bronchodilating effect of salmeterol. Therefore, there seems to be a differential effect of salmeterol on lung function and the response to UNDW. A similar dissociation has been shown with sodium cromoglycate, which had no effect on lung function, but did block UNDW provocation [24]. Conversely, ipratropium bromide in doses up to $160 \mu \mathrm{g}$ caused bronchodilation, but did not change the response to challenge with UNDW [25].

Other mechanisms are thus likely to be involved in the protective effects of salmeterol against UNDW-induced bronchoconstriction. The term functional antagonism is often used to describe the protective effects of $\beta_{2}$-agonists during provocation tests. $\beta_{2}$-agonists may prevent smooth muscle contraction, irrespective of the constrictor mediator, by acting on a different receptor on the same cell, which opposes this constriction [26]. In this way, pharmacological effects of $\beta_{2}$-agonists are different between smooth muscle relaxation and protection against bronchoconstriction [27]. It has previously been shown that $\beta_{2}$-agonists provide true functional antagonistic protection at the level of the smooth muscle against direct pharmacological stimuli as histamine and methacholine [28]. UNDW, however, is thought not to act directly at the level of the smooth muscle, but to induce airway narrowing indirectly $[9,10]$. Therefore, mechanisms other than bronchodilation and functional antagonism should be considered to explain this apparent dissociation.

O'Connor et al. [29] showed that $\beta_{2}$-agonists have an additional inhibitory nonsmooth muscle effect on bronchoconstrictor stimuli that involve mast cell activation, in affording a greater protection against adenosine monophosphate- than methacholine-induced bronchoconstriction. Salmeterol has several acute anti-inflammatory effects in vitro that may contribute, e.g. the strong inhibition of the release of mast cell mediators [2], involved in the mechanism of action of UNDW. Thus, although the evidence is only indirect, this protection may indicate long-lasting cell-stabilizing effects of salmeterol in vivo up to $20 \mathrm{~h}$ rather than functional antagonism.

Finally, in a number of patients, the protection of salmeterol against UNDW decreased, while bronchodilation persisted. This dichotomy between duration of bronchodilation and protection against a bronchoconstrictor stimulus has already been described by AHRENS et al. [30]. These differences in time course could reflect differences in the mechanism for these two $\beta_{2}$-agonistic actions. However, an alternative explanation could be the differences in potency of the bronchoconstrictor stimulus. A larger concentration of a $\beta_{2}$-agonist may be required to prevent contraction to a potent stimulus as a provocation test, as compared with the concentration of the drug to produce relaxation of the relatively modest level of bronchospasm at baseline [31]. Several studies showed a relationship between bronchodilator dose and the degree of inhibition of provocation [32]. A greater concentration of salmeterol may be required to prevent contraction to UNDW provocation than is required to produce relaxation. However, the concentration of salmeterol required to prevent mast cell mediator release may similarly be higher than the concentration required to prevent contraction of the muscle by the mediators released.

Whether this nonbronchodilator effect of salmeterol also provides clinically relevant effects or persists after prolonged therapy, is at present unclear. No change in BHR was reported after 6 weeks of treatment with salmeterol [7]. On the other hand, salmeterol significantly improved the treatment of (chronic) bronchial asthma and resulted in a clinical significant improvement in quality of life versus placebo and salbutamol [33]. GREENING et al. [34] showed that adding salmeterol to inhaled corticosteroid therapy was more appropriate for patients with inadequately controlled asthma on low-dose inhaled corticosteroids than doubling this dose. Finally, in this study, salmeterol afforded a significant protection of more than $20 \mathrm{~h}$ against a naturally occurring stimulus, which may be very relevant for asthma management.

In conclusion, our study shows that a single dose of salmeterol in mild-to-moderate asthma causes bronchodilation and protection independently of this bronchodilation against a physiological bronchoconstrictor stimulus for more than $20 \mathrm{~h}$.

\section{References}

1. Lötvall J, Svedmyr N. Salmeterol: an inhaled $\beta_{2}$-agonist with prolonged duration of action. Lung 1993; 171 : 249-264.

2. Butchers PR, Vardey CJ, Johnson M. Salmeterol: a potent and long-acting inhibitor of mediator release from human lung. Br J Pharmacol 1991; 104: 672-676.

3. Nelson HS. $\beta$-adrenergic bronchodilators. $N$ Engl J Med 1995; 333: 499-506.

4. Whelan CJ, Johnson M. Inhibition by salmeterol of increased vascular permeability and granulocyte accumulation in guinea-pig lung and skin. Br J Pharmacol 1992; 105: 831-838.

5. Beach JR, Young CL, Harkawat R, et al. Effect on airway responsiveness of six weeks treatment with salmeterol. Pulm Pharmacol 1993; 6: 155-157.

6. Gardiner PV, Ward C, Booth H, Allison A, Hendrick DJ, Walters EH. Effect of eight weeks of treatment with salmeterol on bronchoalveolar lavage inflammatory indices in asthmatics. Am J Respir Crit Care Med 1994; 150: 1006-1011.

7. Twentyman OP, Finnerty JP, Harris A, Palmer J, Holgate ST. Protection against allergen-induced asthma by salmeterol. Lancet 1990; 336: 1338-1342.

8 Pedersen B, Dahl R, Larsen BB, Venge P. The effect of salmeterol on the early-and late-phase reaction to bronchial allergen and postchallenge variation in bronchial reactivity, blood eosinophils, serum eosinophil cationic protein, and serum eosinophil protein X. Allergy 1993; 48: 377-382.

9. Smith CM, Anderson SD. Inhalation provocation tests using nonisotonic aerosols. J Allergy Clin Immunol 1989; 84: 781-790. 
10. Mattoli S, Forensi A, Corbo GM, Valente S, Patalano F, Ciappi G. Increase in bronchial responsiveness to methacholine and late asthmatic response after inhalation of ultrasonically nebulized distilled water. Chest 1986; 90: 726-732.

11. Standards for the diagnosis and care of patients with chronic obstructive pulmonary diseases (COPD) and asthma. Am Rev Respir Dis 1987; 136: 225-244.

12. Oosterhoff Y, Koëter GH, De Monchy JGR, Postma DS. Circadian variation in airway responsiveness to methacholine, propanolol, and AMP in atopic asthmatic subjects. Am Rev Respir Dis 1993; 147: 512-517.

13. Cockroft DW, Killian DN, Mellon JA, Hargreave FE. Bronchial reactivity to inhaled histamine; a method and clinical survey. Clin Allergy 1977; 7: 235-243.

14. Groot C, Lammers JW, Festen J, Van Herwaarden C. Refractoriness for ultrasonically nebulized distilled water and histamine after histamine challenge. J Appl Physiol 1991; 70: 1011-1015.

15. Quanjer PH (ed). Standardized lung function testing. Eur Respir J 1993; 6 (Suppl. 16): 1-100.

16. Koch GF. The use of non-parametric methods in the statistical analysis of the two-period change-over design. Biometrics 1972; 28: 577-584.

17. Bland JM, Altman DG. Statistical methods for assessing agreement between two methods of clinical measurement. Lancet 1986; ii: 307-310.

18. Ramsdale EH, Roberts RS, Morris MM, Hargreave FE. Differences in responsiveness to hyperventilation and methacholine in asthma and chronic bronchitis. Thorax 1985; 40: 422-426.

19. Booth H, Fishwick K, Harkawat R, Devereux G, Hindrick DJ, Walters EH. Changes in methacholine induced bronchoconstriction with the long acting $\beta_{2}$ agonist salmeterol in mild to moderate asthmatic patients. Thorax 1993; 48: 1121-1124.

20. Rabe KF, Jörres R, Nowak D, Behr N, Magnussen H. Comparison of the effects of salmeterol and formoterol on airway tone and responsiveness over 24 hours in bronchial asthma. Am Rev Respir Dis 1993; 147: 14361441.

21. Mattoli S, Foresi A, Corbo GM, et al. Refractory period to ultrasonic mist of distilled water: relationship to methacholine responsiveness, atopic status, and clinical characteristics. Ann Allergy 1987; 58: 134-140.

22. Kivity S, Shalit Y, Greif J, Topilsky M. Comparison between refractoriness after distilled water-induced asthma and exercise-induced asthma. Ann Allergy 1989; 62: 180-183.

23. Edmunds AT, Tooley M, Godfrey S. The refractory period after exercise-induced asthma: its duration and rela- tion to the severity of exercise. Am Rev Respir Dis 1978: 117: 247-254.

24. Moscato G, Rampulla C, Dellabianca A, Zanotti E, Candura S. Effect of salbutamol and inhaled sodium cromoglycate on the airway and neutrophil chemotactic activity in "fog"-induced bronchospasm. J Allergy Clin Immunol 1988; 82: 382-388.

25. Groot CA, Lammers JW, Festen J, Van Herwaarden CL. The protective effects of ipratropium bromide and terbutaline on distilled water-induced bronchoconstriction. Pulm Pharmacol 1994; 7: 59-63.

26. Ariens EJ. Pharmacology of airway smooth muscle. In: Nadel JA, Pauwels R, Snashall PD, eds. Bronchial Hyperresponsiveness. Oxford, Blackwell Scientific Publications, 1987; pp. 7-22.

27. Gustafsson B, Persson CGA. Effect of different bronchodilators on airway smooth muscle responsiveness to contractile agents. Thorax 1991; 46: 360-365.

28. Van Amsterdam RGM, Meurs H, Ten Berge RE, Veninga NCM, Brouwer F, Zaagsma J. Role of phosphoinositide metabolism in human bronchial smooth muscle contraction and in functional antagonism by beta-adrenoreceptor agonists. Am Rev Respir Dis 1991; 142: 11241128.

29. O'Connor BJ, Fuller RW, Barnes PJ. Nonbronchodilator effects of inhaled $\beta_{2}$ agonists: greater protection against adenosine monophosphate- than methacholine-induced bronchoconstriction in asthma. Am J Respir Crit Care Med 1994; 150: 381-387.

30. Ahrens RC, Bonhan AC, Maxwell GA, Weinberger MM. A method for comparing the peak intensity and duration of action of aerosolized bronchodilators using bronchoprovocation with methacholine. Am Rev Respir Dis 1984: 129: 903-906.

31. Tashkin DP. Measurement and significance of the bronchodilator response: bronchodilation and inhibition of bronchoprovocation. In: Spector SL, ed. Provocation Testing in Clinical Practice. NY. Marcel Dekker Inc. 1994: pp. 513-573.

32. Britton J, Hanley S,. Garrett HV, Hadfield JW, Tattersfield AE. Dose-related effects of salbutamol and ipratriopium bromide on airway calibre and reactivity in subjects with asthma. Thorax 1988: 43: 300-305.

33. Juniper EF, Johnston PR, Borkhoff CM, Guyatt GH, Boulet L-P, Haukioja A. Quality of life in asthma clinical trials: comparison of salmeterol and salbutamol. $\mathrm{Am}$ J Respir Crit Care Med 1995; 151: 66-70.

34. Greening AP, Ind PW, Northfield M, Shaw G. Added salmeterol versus higher-dose corticosteroid in asthma patients with symptoms on existing inhaled corticosteroid. Lancet 1994; 344: 219-224. 